\title{
Correlation between Osteoarthritis Knee Damage Based on Ultrasound with Kellgren-Lawrence Classification
}

\author{
Hubungan antara Kerusakan Lutut Osteoartritis Berdasarkan Ultrasonografi dengan Klasifikasi \\ Kellgren-Lawrence
}

\author{
Wensri Sevni ${ }^{1^{*}}$, Muhammad Ilyas ${ }^{1}$, Mirna Muis ${ }^{1}$, Andi Alfian $Z^{2}$, Faridin ${ }^{3}$, Sri Asriyani ${ }^{1}$ \\ ${ }^{1}$ Department of Radiology, Faculty of Medicine, Hasanuddin University \\ 2Department of Public Health / Family medicine Science, Faculty of Medicine, Hasanuddin University \\ ${ }^{3}$ Department of Internal Medicine Faculty of Medicine, Hasanuddin University
}

DATA OF ARTICLE:

Received: 15 Oct 2019

Reviewed: 25 Jun 2020

Revised: 10 Feb 2021

Accepted: 24 Feb 2021

\section{*CORRESPONDENCE:}

wensrisevni9@gmail.com

DOI:

10.18196/mmjkk.v21i1.7225

TYPE OF ARTICLE:

Research

\begin{abstract}
The classic standard criteria to diagnose osteoarthritis (OA) of the knee is the conventional radiological imaging. Ultrasonography could assess the osteoarthritis early and show invisible joint structures in osteoarthritis. This study aimed to compare the cartilage changes of trochlear femur and osteophytes (femur and tibia) through ultra-sound examination with the radiological imaging in stages to Kellgren-Lawrence (KL) classification. This is an observational study using cross-sectional design, involved 33 patients with knee OA who underwent conventional photo examination and ultrasonography at $\mathrm{dr}$. Wahidin Sudirohusodo Makassar Hospital in the period of June - August 2019. Spearman's test showed that there is a significant correlation between the stage of $\mathrm{OA}$ by $\mathrm{KL}$ and the stage of femoral trochlear cartilage damage ( $\mathrm{p}$ 0.001) with strong correlation (r 0.828). Significant correlation is also between the stage of $\mathrm{OA}$ and the stage of osteophytes on the femur-lateral condyles both medial and lateral sides ( $\mathrm{p} 0.001$ ) with strong correlation ( $\mathrm{r} 0.823 ; 0.79 ; 0.816$, and 0.818 ). It concluded that the higher grade of femoral trochlear cartilage damage will result in the higher the stage of OA. The higher grade of osteophytes in knee joints will also result in the higher the stage of $\mathrm{OA}$.
\end{abstract}

Keywords: osteoarthritis; Kellgren-Lawrence; ultrasound; throchlear femur cartilage; osteophyte condyles femur-tibia

Abstrak: Kriteria standar klasik untuk menegakkan diagnosis osteoartritis (OA) lutut adalah pencitraan radiologis konvensional. Ultrasonografi, dapat menilai osteoartritis lebih awal dan menunjukkan struktur sendi yang tidak terlihat pada pasien osteoartritis. Penelitian ini dilakukan untuk mengetahui perubahan tulang rawan trochlear femur dan osteopfit (femur dan tibia) melalui pemeriksaan ultrasonografi dibandingkan dengan pencitraan radiologi konvensional secara bertahap hingga klasifikasi osteoartritis Kellgren-Lawrence $(K L)$. Jenis penelitian observasional dengan metode potong lintang melibatkan 33 partisipan. Penelitian ini dilakukan pada pasien OA lutut yang menjalani pemeriksaan foto konvensional dan ultrasonografi lutut di instalasi radiologi sentral RSUP dr. Wahidin Sudirohusodo Makassar periode Juni-Agustus 2019. Uji Spearman dilakukan dengan hasil nilai p 0,001 $(<0,05)$. Hal ini menunjukkan bahwa terdapat hubungan signifikan antara stadium OA dengan KL pada stadium kerusakan tulang rawan trochlear femoralis. Korelasi yang signifikan juga ditemukan antara stadium osteofit pada femurlateral condyles baik sisi medial maupun lateral dengan stadium osteartritis (p 0,001). Kekuatan korelasi kuat yang ditunjukkan dengan nilai $r$ masing-masing 0,823;0,79; 0,816 dan 0,818. Disimpulkan bahwa tingkat kerusakan tulang rawan trochlear femoralis yang lebih tinggi akan menghasilkan tingkat OA yang lebih tinggi. Tingkat osteofit yang lebih tinggi pada sendi lutut juga akan menghasilkan stadium OA yang lebih tinggi.

Kata kunci: osteoarthritis; Kellgren-Lawrence; ultrasonografi; kartilago femur throchlea; osteofit condyles femur-tibia 
Arthritis is a general term to describe a joint that experiences pain, stiffness and inflammation. Osteoarthritis $(\mathrm{OA})$ is a degenerative disease of the joints, generally occurs at the age above 50 years with the characteristics of the cartilage degradation, bone hypertrophy at the edges (osteophytes), subchondral sclerosis and biochemical and morphological changes in the synovial membrane area and joint capsule. The classic standard criteria for conventional radiological imaging to establish the diagnosis and classify the stage of osteoarthritis of the knee is the Kellgren-Lawrence $(\mathrm{KL})$ classification system; this system will assess the presence of osteophyte, narrowing joint gap and changes in bone morphology. While the conventional radiological examination is very limited in evaluating soft tissue changes and others changes related to inflammation, ultrasonography, on the other hand, could assess invisible joint structures on conventional photo examinations in osteoarthritis patients. ${ }^{1,2,3,4}$

This study was conducted to examine cartilage changes of trochlear femur and osteophytes (femur and tibia) through ultrasonography examination. The purpose of this study is to assess the correlation between trochlear of femur and osteophyte condyles femur-tibia damage in stages to Kellgren-Lawrence classification of osteoarthritis. In this study, it is expected that there is a match between the stages of trochlear of femur cartilage and femoral-tibia osteophyte damage based on ultrasonography with the stages of osteoarthritis according to the Kellgren-Lawrence classification on conventional radiography. This research is expected to take part in promoting the use of ultrasound in assessing musculoskeletal diseases including in patients with osteoarthritis; Ultrasound could also assess the joint structures, in which the conventional photo examination could not. ${ }^{5,6}$

\section{MATERIALS AND METHOD}

This is an observational study using cross-sectional method to examine the correlation between trochlear of femur and osteophyte condyles femur-tibia damage in stages to Kellgren-Lawrence classification of osteoarthritis in conventional radiological imaging. The minimal number of patients in this study were 32 samples of osteoarthritis patients using consecutive sampling method. The estimated sampling size ( $n$ ) was calculated using the formula below:

$$
n=\left[\frac{Z \propto+Z \beta}{0.51 n \frac{1+r}{1-r}}\right]^{2}+3
$$

Type I Error $=5 \%$, null hypothesis Za $=1.64$

Type II Error $=10 \%$, then $Z \beta=1.28$

$r=0,5$

$$
\begin{aligned}
& n=\left[\frac{1.64+1.28}{0.51 n \frac{1+0.5}{1-0.5}}\right]^{2}+3 \\
& n=32
\end{aligned}
$$

The study used 33 samples that were diagnosed as patient primary osteoarthritis according to the American College of Rheumatology criteria in Rheumatology Department in Wahidin Sudirohusodo Hospital. These research samples are men and women over 50 years old without any history of trauma. The osteoarthritis patient was taken as an outpatient or inpatient care at Dr. Wahidin Sudirohusodo Hospital from June to August 2019 and fulfilled the inclusion criteria. The sample that was diagnosed with primary knee osteoarthritis got their conventional knee photo taken and examined by radiology specialists according to the Kellgren-Lawrence classification. After that, the sample went through knee ultrasonography examination using a transducer linear with frequency 7-15 MHz in supine position. The results of the conventional imaging and ultrasonography was recorded and examined according to statistic method using Spearman correlation test.

\section{a. Conventional Radiography}

In osteoarthritis patients, conventional radiography of the antero-posterior position performed, where the patient holds the load with both knees in extension. This conventional knee photo was then examined by radiology specialists according to the Kellgren-Lawrence classification. In the Kellgren-Lawrence (KL) 
Vol 21 No 1

January 2021

classification system, osteoarthritis is divided into 4 grading. ${ }^{4}$ The grades $1-2$ highlighted the findings of osteophytes while grades 3-4 more focused on the narrowing of the joint gap.

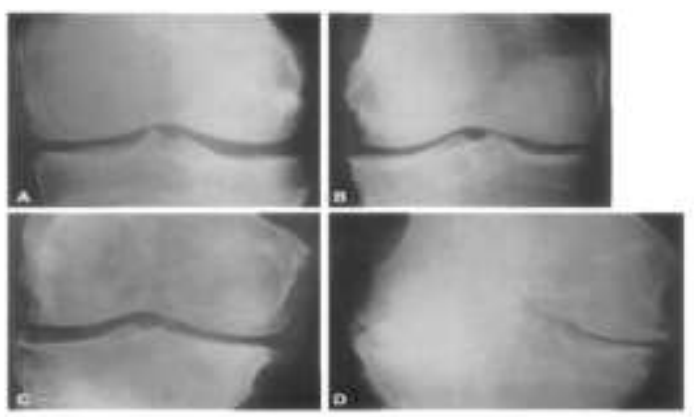

Figure 1: Radiographs of the knee presented in the classification of KL. (A) Representative knee radiograph of KL classification Grade 1, which demonstrates doubtful narrowing of the joint space with possible osteophyte formation. (B) Representative knee radiograph of KL classification Grade 2, which demonstrates possible narrowing of the joint space with definite osteophyte formation. (C) Representative knee radiograph of KL classification Grade 3, which demonstrates definite narrowing of joint space, moderate osteophyte formation, some sclerosis, and possible deformity of bony ends. (D) Representative knee radiograph of KL classification Grade 4, which demonstrates large osteophyte formation, severe narrowing of the joint space with marked sclerosis, and definite deformity of bone ends. ${ }^{4}$

\section{b. Ultrasonography}

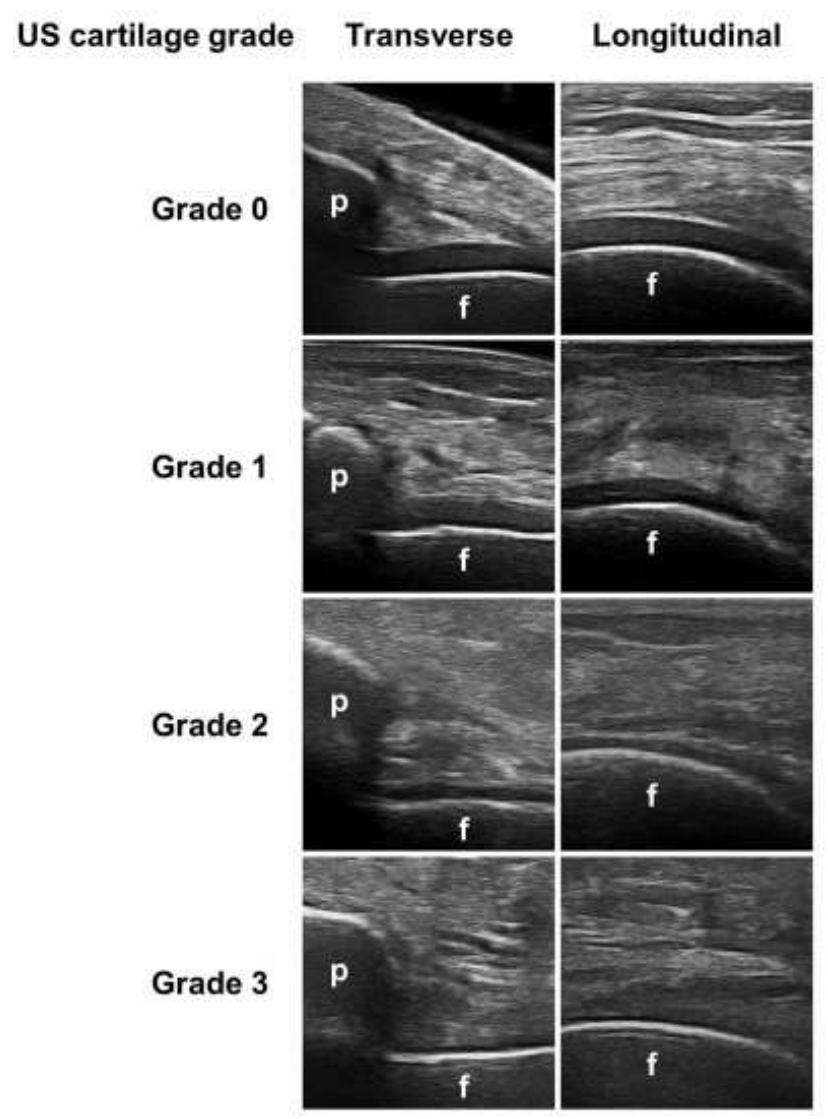

Musculoskeletal ultrasound (USG) examination using a transducer linear with frequency 7-12 MHZ. OA knee patients were examined with ultrasound to assess cartilage trochlear of femur and femur-tibia osteophyte condyles on the medial and lateral sides. ${ }^{7,8}$ On this research, we only use one of the patient's knees according 
Vol 21 No 1

January 2021

to the OA grading value on the conventional photo. Trochlear femur cartilage examination is taken in the anterior compartment with the knee fully flexed with transverse transducer position. Description of cartilage damage trochlear femur on ultrasonography was divided into 4 grading. ${ }^{9}$ Grade 0 ; shows the homogeneity of anechoic matrix cartilage with anterior edges and clear posterior. Grade 1; indicates the obfuscation or obliteration of cartilage edge. Grade 2; shows fatigue accompanied by obliteration of the cartilage edge as well narrowing of the cartilage band. Grade 3 if the cartilage band cannot be visualized.

An ultrasound examination to assess condyles femur and tibia were taken on the medial and lateral compartments are in the longitudinal transducer position parallel to the cortex femur bone and tibia bones tend to osteophyte findings on ultrasonography divided into 5 grading. Grade 0; no osteophytes, femoral condyles and tibia appear regular. Grade 1; osteophyte minor, only a small protrusion of the femoral condyles and tibia. Grade 2; small osteophytes are prominent on the surface of the condyles femoral and tibia, as well as large osteophytes separated from the surface of the condyles but has an inferior part in the joint space. Grade 3; large osteophytes appear with the inferior part in the joint space while the superior part slightly parallel to the femur and tibia. Grade 4; osteophytes largely parallel to the femur and tibia as well as little or no part in the inferior of joint space. ${ }^{10}$

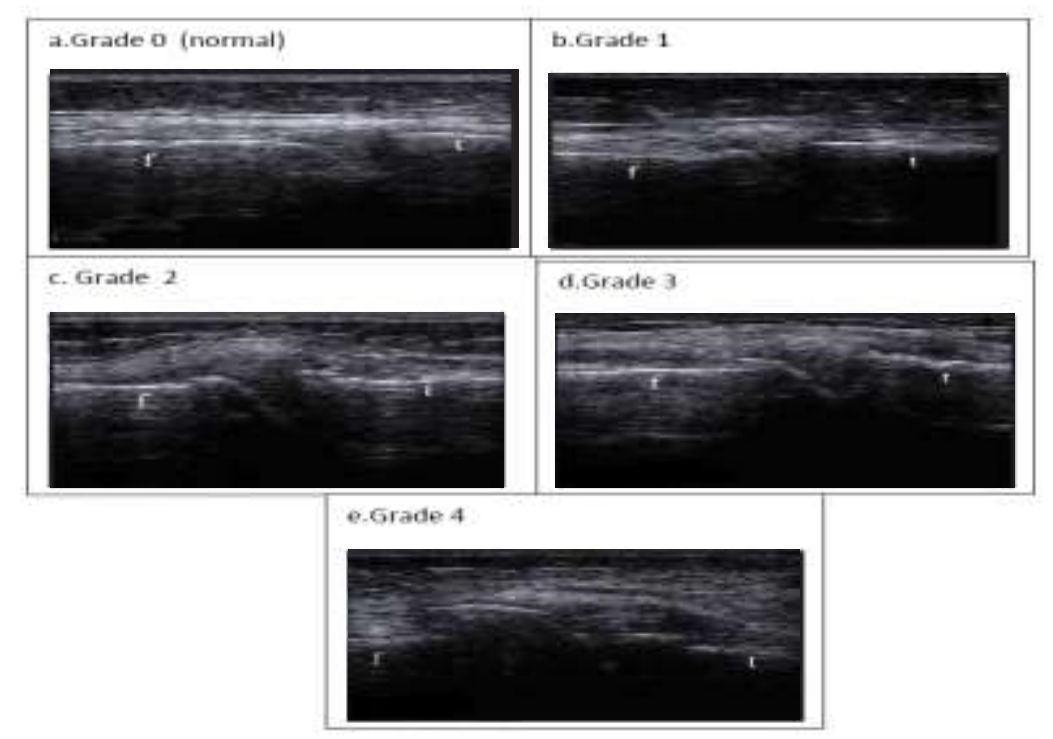

Figure 3: Overview of osteophytes on ultrasound examination ${ }^{10}$

\section{RESULTS}

The data analysis consists of descriptive and Spearman correlation test. Descriptive analysis was conducted to see the number and percentage distribution characteristics for sex, age, body mass index (BMI), stage of OA of the knee by using a conventional photo KL classification, stage of femoral trochlear cartilage, osteophytes stage condyles medial and lateral femur, tibia condyles osteophyte stage medial and lateral knee by ultrasound. The number of patients in this study were 33 samples of osteoarthritis patients. Spearman's test was conducted to analyze the correlation between the stages of knee OA based on photographs of conventional (Classification KL) with the stages of damage to structures of the knee (cartilage and osteophytes) based on ultrasonography. Spearman correlation test results determined that there is a relationship statistically significant if $\mathrm{p}<0.05$. 
Vol 21 No 1

January 2021

Table 1. Osteoarthritis Patients Distribution by Age, Sex and Body Mass Index

\begin{tabular}{ccccc}
\hline Characteristics & & $\mathrm{N}$ & $\%$ & $\boldsymbol{\Sigma}_{\mathbf{n}}$ \\
\hline \multirow{2}{*}{ Sex } & Male & 14 & 42.4 & 33 \\
& Female & 19 & 57.6 & \\
\multirow{2}{*}{ Age } & $51-60$ & 13 & 39.4 & 33 \\
& $61-70$ & 13 & 39.4 & \\
& $>70$ & 7 & 21.2 & 33 \\
BMI & Normal & 22 & 66.7 & \\
& Pre-Obese & 8 & 24.2 & \\
& Obese & 3 & 9.1 & \\
\hline
\end{tabular}

Source: Primary Data, description (n): Summary

Table 1 show the distribution of samples by sex. It appears that there are more female OA sufferers than male. There are 19 (57.6\%) female sufferer compared to male who recorded 14 sufferer (42.4\%). The distribution which is based on the age of patients suffering from OA shows that the high case are in group of 51-50 years and 61-70 years with the same number (39.4\%), while the group of $>70$ years is lower with only $21.2 \%$ cases. The distribution of OA patients based on BMI shows that majority of people with OA have a normal BMI. It looks that there are 22 patients (66.7\%) have a normal BMI, pre-obese are 8 patients (24.2\%) and only 3 patients $(9.1 \%)$ are obese.

The distribution of OA patients by severity according to conventional radiography is shown in Table 2 . It shows that the largest OA cases is in grade 2 with 10 patients (30.3\%), and the smallest is at grade 3 with 6 patients (18.2\%).

Table 3 illustrates the distribution of the sample based on the stage of damage to the femoral trochlear cartilage by ultrasound. The table shows the patients with grade 2 femoral cartilage damage having the most samples $10(30.3 \%)$ and we could still find a picture of normal cartilage in OA patient samples as many as 6 samples (18.2\%).

Table 2. Distribution of OA Patients Based on Severity According to Kellgren Lawrence Classification (Conventional Radiography)

\begin{tabular}{lccc}
\hline \multicolumn{1}{c}{ OA Stage } & $\mathrm{n}$ & $\%$ & $\boldsymbol{\Sigma} \mathbf{n}$ \\
\hline First Grade & 9 & 27,3 & 9 \\
Second Grade & 10 & 30,3 & 19 \\
Third Grade & 6 & 18,2 & 25 \\
Fourth Grade & 8 & 24,2 & 33 \\
\hline
\end{tabular}

Source: Primary Data, description (n): Summary

Table 3. Distribution of OA Patients Based on Stages of Trochlear Femur Cartilage Damage on Ultrasonography

\begin{tabular}{lccc}
\hline $\begin{array}{l}\text { Stages of Trochlear Femur Cartilage } \\
\text { Damage }\end{array}$ & $\mathrm{n}$ & $\%$ & $\boldsymbol{\Sigma} \mathbf{n}$ \\
\hline Normal & 6 & 18.20 & 6 \\
First Grade & 8 & 24.20 & 14 \\
Second Grade & 10 & 30.30 & 24 \\
Third Grade & 9 & 27.30 & 33 \\
\hline
\end{tabular}

Source: Primary Data, description (n): Summary 
Vol 21 No 1

January 2021

Table 4. Distribution of OA Patients Based on Osteophyte Stages on Ultrasonographic Examination

\begin{tabular}{cccc}
\hline Location & Osteophyte Stage & $\mathrm{n}$ & $\%$ \\
\hline Medial Femoral Condyles & Normal & 3 & 9.10 \\
& $1^{\text {st }}$ Grade & 5 & 15.20 \\
& $2^{\text {nd }}$ Grade & 5 & 15.20 \\
& $3^{\text {rd }}$ Grade & 4 & 12.10 \\
& $4^{\text {th }}$ Grade & 16 & 48.50 \\
Lateral Femoral Condyles & Normal & 5 & 15.20 \\
& $1^{\text {st }}$ Grade & 5 & 15.20 \\
& $2^{\text {nd }}$ Grade & 5 & 15.20 \\
& $3^{\text {rd }}$ Grade & 6 & 18.20 \\
Medial Tibia Condyles & $4^{\text {th }}$ Grade & 12 & 36.40 \\
& Normal & 4 & 12.10 \\
& $1^{\text {st }}$ Grade & 7 & 21.20 \\
& $2^{\text {nd }}$ Grade & 3 & 9.10 \\
& $3^{\text {rd }}$ Grade & 4 & 12.10 \\
& $4^{\text {th }}$ Grade & 15 & 45.50 \\
& Normal & 5 & 15.20 \\
& $1^{\text {st }}$ Grade & 8 & 24.20 \\
& $2^{\text {nd }}$ Grade & 3 & 9.10 \\
& $3^{\text {rd }}$ Grade & 5 & 15.20 \\
& $4^{\text {th }}$ Grade & 12 & 36.40 \\
\hline
\end{tabular}

Source: Primary Data, description (n): Summary

Table 5. Correlation between the Stage of OA According to the Kellgren-Lawrence Classification with the Stage of Damage to the Throchlear Femur Cartilage Using Spearman Test

\begin{tabular}{|c|c|c|c|c|c|c|c|}
\hline \multirow{2}{*}{$\begin{array}{l}\text { Stages of Femur } \\
\text { Cartilage Damage }\end{array}$} & \multicolumn{4}{|c|}{ Osteoarthritis Stage } & \multirow{2}{*}{$\mathrm{n}$} & \multirow{2}{*}{$\mathrm{p}$} & \multirow{2}{*}{$\mathrm{r}$} \\
\hline & $1^{\text {st }}$ Grade & $2^{\text {nd }}$ Grade & $3^{\text {rd }}$ Grade & $4^{\text {th }}$ Grade & & & \\
\hline Normal & 5 & 1 & 0 & 0 & 6 & & \\
\hline First Grade & 4 & 3 & 1 & 0 & 8 & 0.001 & 0.828 \\
\hline Second Grade & 0 & 5 & 4 & 1 & 10 & & \\
\hline Third Grade & 0 & 1 & 1 & 7 & 19 & & \\
\hline
\end{tabular}

Source: Primary Data

Table 4 illustrates the distribution of samples by the stage of osteophyte. In medial femoral condyles, the grade 4 osteophytes were found with 16 samples (48.5\%) while those with normal or without osteophytes in the medial femoral condyles were 3 samples (9.1\%). Based on the stage of osteophyte at condyles medial of tibia, grade 4 osteophytes were found the highest with 15 samples (45.5\%), the lowest number was in grade 2 with 3 samples (9.1\%) while those who were still normal or invisible osteophytes in the medial tibia condyles were 4 samples (12.1\%). Based on the stages of lateral femoral condyles osteophytes, grade 4 osteophytes were found the highest with 12 samples (36.4\%) while those who were still normal or not visible osteophytes in the lateral femoral condyles were 5 samples (15.2\%). Based on the stage of osteophytes lateral tibia condyles, grade 4 osteophytes were found the highest with 12 samples (36.4\%) whereas the lowest is in grade 2 with 3 samples (9.1\%) while those who were still normal or invisible osteophytes in lateral tibia condyles were 5 samples (15.2\%).

Table 5 shows that there are five samples of patients with osteoarthritis of Grade 1 who still has a normal femoral trochlear cartilage while there were 7 samples of Grade 4 OA patients who have a stage of cartilage damage Grade 3. With the results of the correlation analysis obtained by the $p$ value of $0.001(<0.05)$, it could be concluded that there is a significant correlation between the stage of OA by KL with the stage of femoral trochlear cartilage damage and has strong correlation with $r$ value of 0.828 . 
Table 6. Correlation between the Stage of OA According to the Kellgren-Lawrence Classification with the Stage of Osteophytes in the Medial Femur Condyles Using Spearman Test

\begin{tabular}{ccc}
\hline \multirow{2}{*}{ Osteophyte Stage } & \multicolumn{3}{c}{ Osteoarthritis Stage $(\mathrm{n}=33)$} \\
\cline { 2 - 3 } & $\mathrm{p}$ & $\mathrm{r}$ \\
\hline Normal & 0.001 & 0.823 \\
First Grade & 0.001 & 0.79 \\
Second Grade & 0.001 & 0.816 \\
Third Grade & 0.001 & 0.818 \\
\hline
\end{tabular}

Source: Primary Data

Table 6 indicates a significant correlation between the stage of osteophytes on the femur-lateral condyles both medial and lateral sides with a stage of ostearthritis where a P value of $0.001(<0.05)$. The correlation is strong with $r$ values of 0.823 (medial condyles femur), 0.79 (medial tibia condyles), 0.816 (lateral condyles femur) and 0.818 (lateral tibial condyles).

\section{DISCUSSION}

In the results of the study shown in Table 1, it was found that more women suffer from OA compared to men. Although women have a smaller prevalence of OA than men when they are under 50 years of age, after the age of 50 years the prevalence increases in women, especially in the knee. This may be caused by the presence of postmenopausal estrogen deficiency after the age of 50 years. This sentence is in line with Price and Wilson's study which found the herbendens node was 10 times more common in women compared to men. ${ }^{11,12}$

At the final stage of $O A$, the symptoms usually receded, in addition to the patient's old age, many patients with the age above 71 no longer go to health facilities. In the Framingham OA study, ${ }^{13}$ the prevalence of knee OA were found 1420 subjects with aged 60 years and higher. The prevalence of radiographic OA is increased with each decade of life from 33\% among those aged 60-70 to $43.7 \%$ among those over 80 years of age. Whereas in Indonesia the prevalence of OA is quite high at $5 \%$ at the age of $>40$ years, 30\% at age $40-60$ years and $65 \%$ at age of above 61 .

Obesity is a risk factor and can make OA worsen. In addition to the effects of excess weight which must be tolerated by the knee in the weight bearing line, active adipose tissue is recognized in active metabolism that contributes to inflammation of the knee. Active adipose tissue increases the synthesis of proinflammatory cytokine such as leptin, adiponectin, resistin, interleukin-1 (IL-1), IL-6, and tumor necrosis factor (TNF). In this study only 3 samples of obese OA patients were obtained ${ }^{11,14}$.

Kellgren-Lawrence classification grade $\geq 2$ is indicated by the presence of osteophytes and grade $\geq 3$ are indicated by narrowing of the joint gap. In several epidemiology studies, there are several different opinions regarding the prevalence of $O A$ grading according to Kellgren-Lawrence. Preliminary studies on Caucasian ethnicities in the United States and Europe show that the prevalence of OA with KL grade $\geq 2$ there are 30-40\% whereas in Asia a higher prevalence is obtained, which is $60 \%$. Then in the Johnston study and the National Health and Nutrition Examination Survey (NHANES) study reported in Africa-America has a radiological prevalence of knee $O A$ that is higher than Caucasian. This shows the difference in prevalence is found according to $\mathrm{KL}$ grading which prioritizes osteophytes and narrowing of joint gaps. This is influenced by several factors involved in the formation of osteophytes and joint gaps in addition to the differences in subjectivity in assessing osteophytes in conventional radiography. ${ }^{15}$

The loss of the classic composition of the cartilage is observed in patients with OA may be preceded by a focal process that manifests early on the surface area of the cartilage. The next step will be superficial cartilage fibrillation followed by a change in the composition of the cartilage which will give an idea of the loss of cartilage edge sharpness and reduced cartilage homogeneity on ultrasonographic examination (Grade 1). Focal lesions on these cartilages will then result in reduced cartilage volume that appears on ultrasonography as a narrowing of the cartilage band (Grade 2). The final stage can come to a state where there are no more 
cartilages, which in ultrasound examination found cartilage bands that can no longer be visualized (grade 3). ${ }^{16,17,18}$ The severity of the trochlear cartilage damage is in line with the stages of OA, this has been supported by many past researchers. Okano's research also showed a strong correlation between narrowing of the tibio femoral joint in OA patients by grading cartilage damage using ultrasonography. 9

In this study, the stage of damage to Grade 2 cartilage on ultrasonography revealed as 5 cartilage thinning was found in 5 samples in Grade 2 OA patients (KL classification). Whereas in Grade 2 OA according to $\mathrm{KL}$ classification, no narrowing of the joints has been found. This can show that cartilage depletion does not absolutely reflects the narrowing of the joint gap. The study of Malas et al (2014) cit. Okano et al (2016), compared US meniscal bulging measurements and radiological $\mathrm{KL}$ grade and found a positive correlation. These results suggest that join space narrowing on radiograph may be affected by meniscal involvement and is not equal to cartilage loss 9,16

In this study out of 33 OA patients there were several patients that did not have osteophytes on either side of the condyles femur or the tibia condyles. The formation of osteophytes begins to grow on the medial side of the femur. Besides, the medial compartment is a weight bearing point. ${ }^{19,20}$ The correlation between the stage of $\mathrm{OA}$ based on $\mathrm{KL}$ classification with the stage of osteophytes, showed that found a significant correlation $(p<0.001)$ and the strength of the strong correlation with the value $(r)$ were all $>0.7$. Where the heavier the stage of OA the heavier the stage of osteophytes. Some studies also suggest the same thing. Serban and Okano's research also showed a strong correlation between the stage of OA (KL) and the stage of osteophytes on ultrasonographic examination. ${ }^{9,16}$

\section{CONCLUSION}

There is a significant positive correlation between trochlear femur cartilage damage and the stage of osteophytes on ultrasonographic examination with the stage of OA according to the KL classification on conventional radiography. The higher grade of femoral trochlear cartilage damage will result in the higher the stage of OA. The higher grade of osteophytes in knee joints will also result in the higher the stage of OA.

\section{REFERENCES}

1. PAPDI. Rekomendasi IRA untuk Diagnosis dan Penatalaksanaan Osteoarthritis. 2014. https://reumatologi.or.id/wp.content/uploads/2020/10/Rekomendasi_Osteoarthritis_2014.pdf

2. Goldring SR and Goldring MB. Clinical Aspects, Pathology and Pathophysiology of Osteoarthritis. J Musculoscelet Neuronal Interact. 2006 Oct-Dec; 6 (4): p. 376-378

3. 3.Vincent KR, Conrad BP, Fregly BJ, Vincent HK. The pathophysiology of osteoarthritis: a mechanical perspective on the knee joint. Physical Medicine $\mathcal{E}$ Rehabilitation. 2012: (4), S3-S9:p. 1-11

4. Kohn MD, Sassoon AA, Fernando ND. Classification in Brief: Kellgren-Lawrance Classification of Osteoarthritis. Clin Orthop Relat Res. 2016 Aug; 474(8): 1886-1893. doi: 10.1007/s11999-016-4732-4

5. 5.Iagnocco A. Imaging the joint in osteoarthritis: a place for ultrasound? Best Pract Res Clin Rheumatol. 2010 Feb;24(1):27-38. doi: 10.1016/j.berh.2009.08.012

6. 6.Pineda C, Hernandez C, Angelica P, Villaseñor-Ovies P. The Place of Ultrasonography in Knee joint Osteoarthritis: an update. International Journal of Clinical Rheumatology 6(6):635-642. DOI: $10.2217 /$ ijr. 11.59

7. Alves TI, Girish G, Brigido MK, Jacobson JA. US of the knee: Scanning Techniques, Pitfalls, and Pathologic Conditions. Radiographics. 2016 (36);6:1759-1775. doi.org/10.1148/rg.2016160019

8. 8.Pissara AP, Madaleno RRD, Graca B, Cruz F, Carvalheiro V, Alves C. Knee Ultrasonography: Scanning Technique and MRI. European Society of Radiology. 2016; 1-38. Doi 10.1594/ecr2016/C-1556

9. Okano T, Filippucci E, Di Carlo M, Draghessi A, Carotti M, Salaffi F, et al. Ultrasonographic Evaluation of Joint Damage in Knee Osteoarthritis: Feature-Specific Comparisons with Coventional Radiography. Rheumatology (Oxford). 2016 Nov; 55 (11): p. 2040-2049. DOI: 10.1093/rheumatology/kew304

10. Mortada M, Zeid A, Al-Toukhy MAE, Ezzeldin N, and Elgawish M. Reliability of a Proposed Ultrasonographic Grading Scale for severity of Primary Knee Osteoarthritis. Clin Med Insights Arthritis Musculoskelet Disord. 2016; 9: p. 161-166. doi: 10.4137/CMAMD.S38141

11. 11.Paul E, Haudenschild D, Samuel J. Kelley's Textbook of Rheumatology-9 ${ }^{\text {th }}$ ed: Phatogenesis of Osteoarthritis. Elsevier, (98). 2013; p.1617-1633

12. Plotnikoff R, Karunamuni N, Lytvyak E, Penfold C, Schopflocher D, Imayama I et al. Osteoarthritis prevalence and modifiable factors: a population study. BMC Public Health. 2015 Nov 30;15:1195. doi: 10.1186/s12889-015-2529-0. 
13. Anderson AS and Loeser RF. Why is Osteoarthritis an Age related Disease?. Best Pract Res Clin Rheumatol. 2010 Feb; 24 (1): p. 15-26. doi: 10.1016/j.berh.2009.08.006

14. Ashkavand Z, Malekinejad H, Vishwanath,B. The Pathophysiology of Osteoarthritis. Journal of Pharmacy Research. January 2013: 7(1):132-138. Doi 10.1016/j.jopr.2013.01.008

15. Muraki S, Tanaka S, Yoshimura N. Epidemiology of Knee Osteoarthritis. OA Sport Medice.London. 2013 Nov 26; 1 (3): 21: p. 1-6. http://www.oapublishinglondon.com/images/article/pdf/1405806524.pdf

16. Serban O, Porojan M, Deac M, Cozma F, Solomon C, Lenghel M et al. Pain in Bilateral Knee Osteoarthritis-Correlations between Clinical Examination, Radiological and Ultrasonographical Finding. Medical Ultrasonography September 2016: 18 (3): p. 318-325.

17. Podlipská J, Koski JM, Kaukinen P, Haapea M, Tervonen O, et al. Structure-symptom relationship with wide-area ultrasound scanning of knee osteoarthritis. Scientific Reports, 2017(7):44470. 1-10. doi 10.1038/srep44470.

18. Poole AR, Guilak F, Abramson SB. Etiopathogenesis of Osteoarthritis in Moskowitz RW, Altman RD, Hochberg MC. Osteoarthritis. $4^{\text {th }}$ ed. Lippincott Williams and Wilkins, Philadelphia. 2007: 27-49.

19. Thompshon J. Netter's Concise Orthopaedic Anatomy.Leg/knee. Second edition. Elseiver Inc. 2010; p. 297-322

20. Wong SHJ, Chiu KY, Yan CH. Review Article: Osteophytes. Journal of Orthopaedic Surgery: 2016 (24) 3: 403-10. doi.org/10.1177/1602400327 